\title{
A Qualitative Model of the Interaction of Sexual Behavior and Hormone Gene Transcription in Male Blue Gourami during Reproduction
}

\author{
Gad Degani1,2 \\ ${ }^{1}$ MIGAL-Galilee Research Institute, Kiryat Shmona, Israel \\ ${ }^{2}$ Faculty of Sciences, Tel-Hai Academic College, Upper Galilee, Israel \\ Email: gad@migal.org.il
}

How to cite this paper: Degani, G. (2020) A Qualitative Model of the Interaction of Sexual Behavior and Hormone Gene Transcription in Male Blue Gourami during Reproduction. Journal of Biophysical Chemistry, 11, 43-50.

https://doi.org/10.4236/jbpc.2020.114004

Received: July 16, 2020

Accepted: October 9, 2020

Published: October 12, 2020

Copyright $\odot 2020$ by author(s) and Scientific Research Publishing Inc. This work is licensed under the Creative Commons Attribution International License (CC BY 4.0).

http://creativecommons.org/licenses/by/4.0/

\begin{abstract}
In the present study, a model is suggested to describe hormone control in male blue gourami (Trichogaster trichopterus) along the gonadotropic brain-pituitarygonad axis (BPG axis) and the hypothalamic-pituitary-somatotropic axis (HPS axis). This model is based on the cloning and transcription of genes encoding hormones of the two axes involved in spermatogenesis during blue gourami reproduction. Gene transcription is affected by environmental, biological, and behavioral factors. Mature males were examined in two different stages-nonreproductive in high-density habitats and reproductive in low-density habitats. Based on gene transcription, gonadotropin-releasing hormone 1 (GnRH1) was involved in controlling spermatogenesis (spermatogonia to spermatids) via the BPG axis in nonreproductive and reproductive stages by controlling follicle-stimulating hormone (FSH), 11-ketotestosterone (11KT) and $17 \beta$-estradiol $\left(\mathrm{E}_{2}\right)$. However, $\mathrm{GnRH} 3$ had a larger effect during the reproductive stage via the BPG axis (spermatids to sperm) on luteinizing hormone (LH), $11 \mathrm{KT}$, and $17 \alpha$-hydroxyprogesterone (17P). At the same time, the HPS axis was involved in spermatogenesis via pituitary adenylate cyclase-activating polypeptide (PACAP) and its related peptide PRP (formerly known as GHRH-like peptide) in the brain, and growth hormone (GH) in the pituitary affected synthesis of insulin-like growth factor 1 (IGF1) in the liver.
\end{abstract}

\section{Keywords}

Qualitative Model, Anabantidae, Hormone, Gene, Trichogaster, Spermatogenesis, Sperm, GnRH, 11-Ketotestosterone, Gonadotropic Brain Pituitary Gonad Axis 


\section{Introduction}

Blue gourami (Trichopodus trichopterus) belongs to the Labyrinithici fish, order Anabantiformes. It is characterized by a specialized organ termed labyrinth, located above its gills, for the respiration of atmospheric oxygen [1]. The geographical distribution of suborder Anabantoidei fish is Central Africa, India, and southern Asia [2]. In its natural habitat, the Anabantoidei fish adapts to an unpredictable environment in which water oxygen concentration varies throughout the year, and can reach a very low percentage, prompting development of the labyrinth organ [1].

Labyrinthici fish undergo two different periods during their life cycle: 1) before labyrinth organ development, from eggs to juveniles, when oxygen is retained over the entire surface by diffusion; 2) after labyrinth development, when the organ becomes important for breathing [1] [3] [4]. The adaptation for the development of eggs and fry in water with low oxygen concentrations involves laying eggs in a bubble nest. The complex sexual and nest-building behaviors of fish belonging to the Anabantoidei species have been described in detail [2] [5] [6] [7]. In natural habitats, when there is a low density of mature males, they become territorial, build a bubble nest and protect it from other males (Figure 1 ). The function of the bubble nest is to supply oxygen to the eggs and larvae in water with very low oxygen concentrations [1].

In blue gourami, as a model Labyrinithici fish for hormonal control of reproduction, the male's sexual behavior [10] and pheromones [11] [12] affect the gonadotropic axis-the brain-pituitary-gonadal (BPG) axis [9] [13], and the somatotropic axis-the brain-pituitary-liver and body (BPLB) axis. These axes are very complex and they control gametogenesis [1] [10] [14]. In the present study, a model is suggested to describe hormone control in male blue gourami.

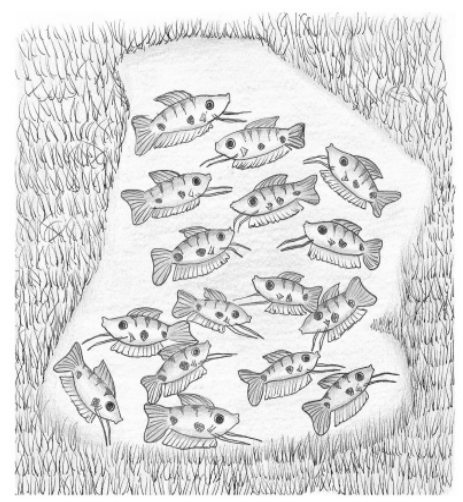

(a)

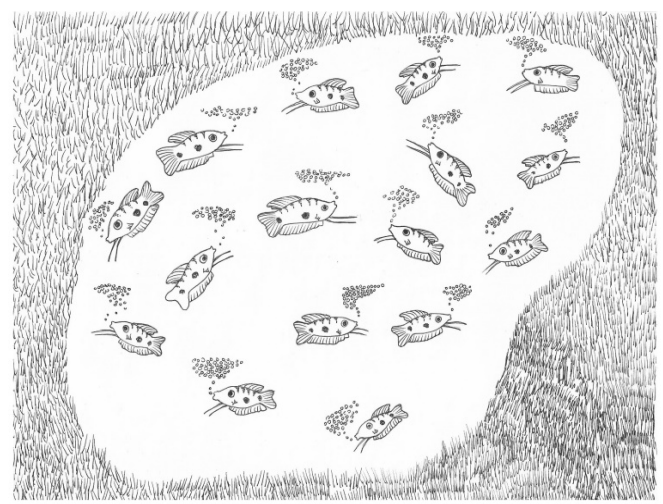

(b)

Figure 1. The two habitats, with high and low densities of males. (a) At high density, the male does not build a nest; (b) At low density, the male builds a nest and sexual behavior [1] [5] [8] [9]. After courting and fertilization, the female swims under the bubble nest and spawns eggs into it. The male guards the nest with the eggs. If an egg falls out, the male returns it to the nest. It also protects the fish in the first period, immediately after hatch (Figure 2). 


\section{Material and Methods}

The sexual and nest-building behaviors of blue gourami males have been described in detail in their natural habitat [1] and under experimental conditions [5] [10]. The cloning of genes encoding various hormones and their mRNA levels have been presented in various papers for different organs of the male blue gourami: in the brain-kisspeptin (KISS1 and 2) [9] [15], gonadotropin-releasing hormone (GnRH1 and 3) [9] [16] [17] and pituitary adenylate cyclase-activating polypeptide (PACAP) [18] and its related peptide (PRP) [18]; in the pituitary gland-follicle-stimulating hormone (FSH) [19] [20], luteinizing hormone (LH) [19] [21], growth hormone (GH) [22] and prolactin (PRL) [23]. Levels of the following steroids have been measured by radioimmunoassay in the plasma and testes: $17 \beta$-estradiol $\left(\mathrm{E}_{2}\right)$, testosterone $(\mathrm{T})$ and $17 \alpha, 20 \beta$-dihydroxy-4-pregnen-3-one $(17,20 \mathrm{P})$ [9] [24] [25] [26], and in the liver: synthesis vitellogenin (VTG) and insulin-like growth factor 1 (IGF1) [22] (Table 1).

\section{Hormones Involved in the Control of Male Reproduction}

Many factors have differential effects on the brains of mature males vs. females [5], including environmental factors such as temperature and water quality, and biological factors such as pheromones and the behavior of other males. Those factors affect the male's sexual behavior, territoriality and nest-building [1] [5] [6] [7] [8] [27] (Figure 1 and Figure 2). Some of the factors are physical, e.g., temperature, water volume, and objects, such as plants, that can upholder the hindernest building. Other parameters involve interactions with other fish, such

Table 1. Describe hormones described involve in male blue gourami (Trichogaster trichopterus) along the gonadotropic brain-pituitary-gonad axis (BPG axis) and the hypothalamic-pituitary-somatotropic axis (HPS axis).

\begin{tabular}{|c|c|c|}
\hline Name of hormones & $\begin{array}{l}\text { The organ or tissue } \\
\text { gene transcription }\end{array}$ & reference \\
\hline Kisspeptin (KISS1 and 2) & Brain & {$[24]$} \\
\hline Gonadotropin-releasing hormone (GnRH1 and 3) & Brain & {$[16][17]$} \\
\hline $\begin{array}{l}\text { Pituitary adenylate cyclase-activating polypeptide } \\
\text { (PACAP) and its related peptide (PRP) }\end{array}$ & Brain & {$[18]$} \\
\hline Follicle-stimulating hormone (FSH) & Pituitary & [19] [22] \\
\hline luteinizing hormone (LH) & Pituitary & {$[19][21]$} \\
\hline Growth hormone $(\mathrm{GH})$ & Pituitary & {$[22]$} \\
\hline Prolactin (PRL) & Pituitary & [23] \\
\hline $17 \beta$-estradiol (E2) & Ovary & [24] [25] [26] \\
\hline Testosterone $(\mathrm{T})$ & Ovary & {$[24][25][26]$} \\
\hline $17 \alpha, 20 \beta$-dihydroxy-4-pregnen-3-one $(17,20 \mathrm{P})$ & Ovary & [24] [25] [26] \\
\hline Vitellogenin (VTG) & Liver & {$[22]$} \\
\hline Insulin-like growth factor 1 (IGF1) & Liver & {$[22]$} \\
\hline
\end{tabular}




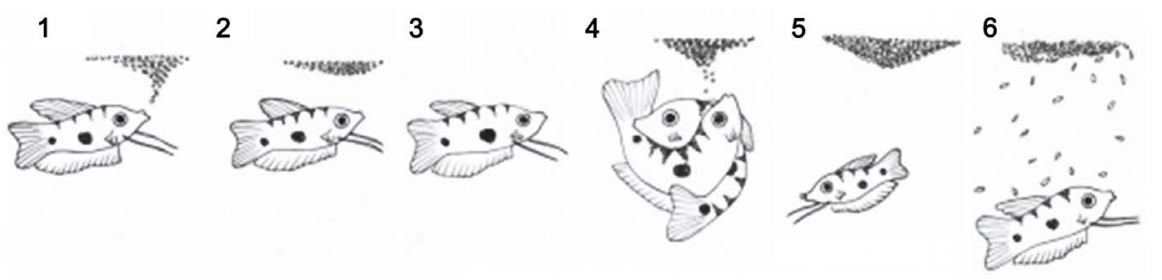

Figure 2. Sexual behavior of male blue gourami during the reproductive cycle. (1) The male builds a nest. (2 and 3) Male courts female under the nest. (4) Fertilization takes place and the fertilized eggs float up and stick to the bubble nest. (5) The male guards the eggs in the nest. (6) The male further protects the fry immediately after hatch while they swim in the nest area.

as fish density and pheromones [1] [5]. It has been suggested that the male blue gourami [28] is found in one of two stages after maturation: nonreproductive and reproductive, dependent on conditions that affect the brain and are controlled by the BPG axis. When the males are found in relatively high densities, there is no sexual behavior (or nest building) [5] [10] (Figure 1). Studies of the transcription of many genes in the BPG axis compared to their transcription during spermatogenesis in the testis have indicated which hormones are involved in spermatogenesis. Based on these results, a qualitative model of the two different male stages, dependent upon their environment, is suggested (Figure 1, Figure 3). In the first stage, males are present at high densities, and no sexual behavior or nest building occurs. In the second stage, males are present at low densities and they build nests and become territorial. This situation gives us the opportunity to examine the changes in genes and hormones occurring in the blue gourami brain and BPG axis [28] under these two distinct conditions, mainly GH [22] and PRL [23]; in the plasma and testis, $\mathrm{E}_{2}, \mathrm{~T}$ and 17, 20P [24] [25] [26]; and in the liver, VTG and IGF1 [22].

Gene transcription and hormone secretion along the BPG axis are involved in spermatogenesis in the testis during male reproduction. These are affected by environment [29], sexual behavior [5] [10], pheromones and kisspeptin (KISS1 and 2) [30], gonadotropin-releasing hormone (GnRH1 and 3) [16] [17], follicle-stimulating hormone (FSH) [19] [20], luteinizing hormone (LH) [19] [21], pituitary adenylate cyclase-activating polypeptide (PACAP) [18] and its related peptide (PRP) [18], growth hormone (GH) [22], and prolactin (PRL) [18]. FSH and $\mathrm{LH}$ act on the ovary to synthesize the steroids $17 \beta$-estradiol $\left(\mathrm{E}_{2}\right)$, testosterone (T) and 17 $\alpha, 20 \beta$-dihydroxy-4-pregnen-3-one (17, 20P) [24] [25] [26]; and on the liver to synthesize vitellogenin (VTG) and insulin-like growth factor 1 (IGF1) [22].

\section{Discussion}

The brain of the male blue gourami is affected by different parameters, and the effects of each individual parameter are difficult to distinguish. The suggested model in Figure 3 shows only the genes encoding hormones that change with sexual behavior. This model suggests that GnRH1 controls spermatogenesis via 


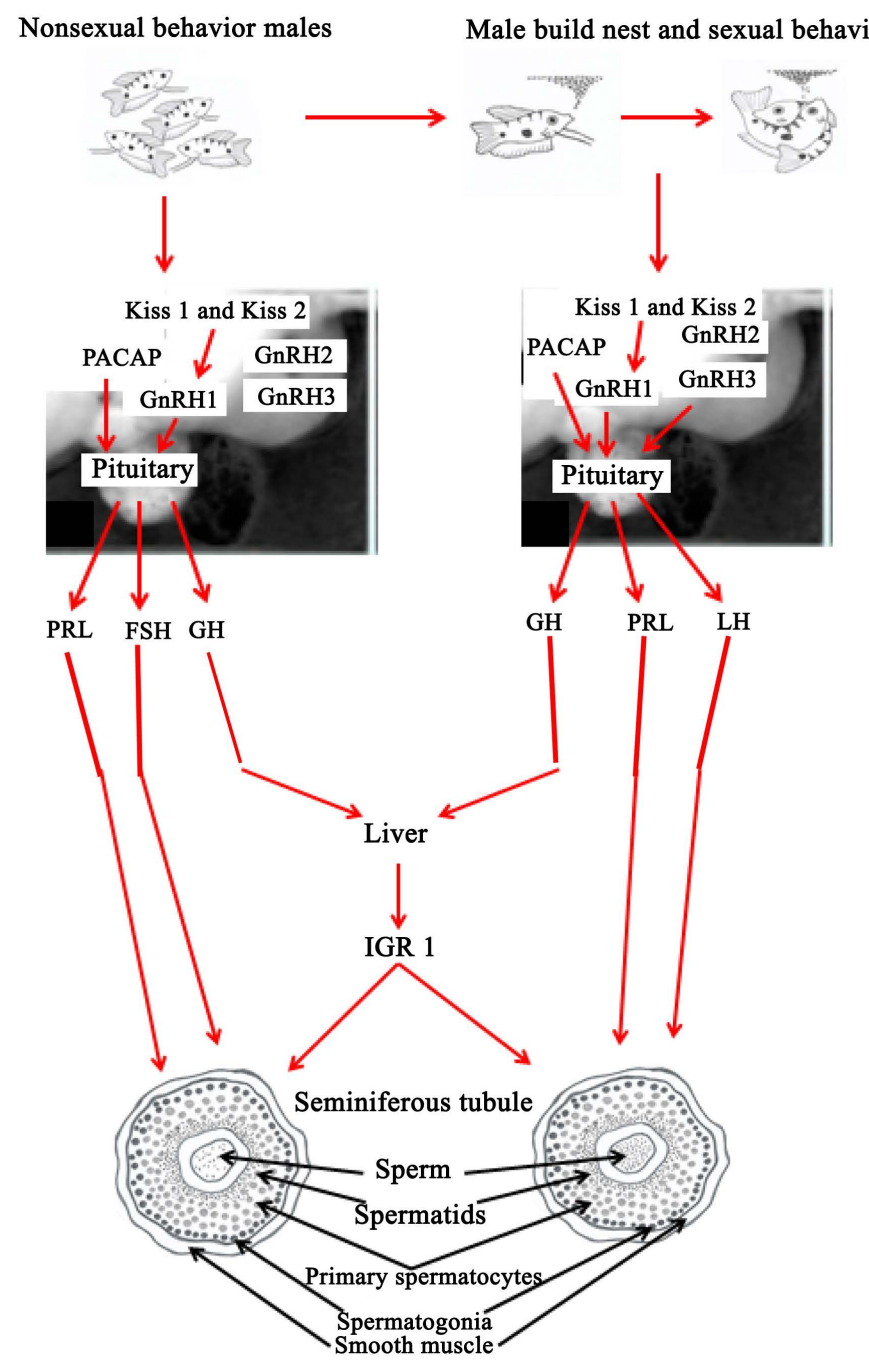

Figure 3. Gene transcription and hormone secretion along the BPG axis involved in spermatogenesis in the testis during male reproduction. These are affected by environment [29], sexual behavior [5] [10], pheromones and kisspeptin (KISS1 and 2) [30], gonadotropin-releasing hormone (GnRH1 and 3) [16] [17], follicle-stimulating hormone (FSH) [19] [20], luteinizing hormone (LH) [19] [21], pituitary adenylate cyclase-activating polypeptide (PACAP) [18] and its related peptide (PRP) [18], growth hormone (GH) [22], and prolactin (PRL) [23]. FSH and LH act on the ovary to synthesize the steroids $17 \beta$-estradiol $\left(\mathrm{E}_{2}\right)$, testosterone $(\mathrm{T})$ and $17 \alpha, 20 \beta$-dihydroxy-4-pregnen-3one $(17,20 \mathrm{P})[24][25][26]$; and on the liver to synthesize vitellogenin (VTG) and insulin-like growth factor 1 (IGF1) [22].

the BPG axis at both stages: before sexual behavior and during sexual behavior [17]. It controls the change from spermatogonia to spermatids through FSH, $11 \mathrm{KT}$ and $\mathrm{E}_{2}$. GnRH3 has a stronger effect via the BPG axis on the change from spermatids to sperm through $\mathrm{LH}, 11 \mathrm{KT}$ and $17 \mathrm{P}$. However, it is very difficult to separate the functions of the hormones controlling the various stages of spermatogenesis that occur continually in blue gourami, as in many Labyrinithici fishes. Testis histology clearly shows the different stages of the sperm cells: spermatogonia, primary spermatocytes, spermatids and sperm [17] [20] in the 
mature males before and during sexual behavior. The only difference was found in the amount of sperm, which increased during sexual behavior. In the model (Figure 3), we suggest that at this stage, GnRH3 affects LH.

The model suggests that in addition to the BPG axis, the BPLB axis also affects spermatogenesis. PACAP transcription is significantly higher in mature vs. juvenile males [20] [30]. It is suggested that this is because the BPLB axis involvement in spermatogenesis (from spermatogonia to sperm) affects GH and IGF1, but not sperm release into the water during sexual behavior. In male-derived cells from the pituitary gland, the GHRH-like peptide PRP significantly increases GH transcription [30]. PACAP transcription was found to be higher in reproducing males in vivo, and GH mRNA level was the same in juvenile, mature and reproducing males [31]. Many published studies support the notion that the somatotropic axis and liver, via GH and IGF1, also modulate reproduction directly and indirectly, along with the BPG axis in both males and females [32]. This situation was found with the hormones involved in spermatogenesis as described in the qualitative model suggested in the present study (Figure 3).

\section{Conflicts of Interest}

The author declares no conflicts of interest regarding the publication of this paper.

\section{References}

[1] Degani, G. (2001) Blue Gourami (Trichogaster trichopterus) Model for Labyrinth Fish. Laser Pages Publishing, Israel, 1-134.

[2] Forselius, S. (1975) Studies of Anabantid Fishes. Parts I, II, III. Zoologiska Bidrag Fran Uppsala, 32, 593-597.

[3] Degani, G. (1991) The Effect of Diet, Population Density and Temperature on the Growth of Larvae and Juveniles of Trichogaster trichopterus (Bloch \& Schneider 1801). Journal of Aquaculture in the Tropics, 6, 135-141.

[4] Degani, G. and Gur, N. (1992) Growth of Juvenile Trichogaster leerii (Bleeker, 1852) on Diets with Different Protein Levels. Aquaculture Research, 23, 161-166. https://doi.org/10.1111/j.1365-2109.1992.tb00606.x.

[5] Degani, G. and Ziv, M.B. (2016) Male Blue Gourami (Trichogaster trichopterus) Nest-Building Behavior Is Affected by Other Males and Females. Open Journal of Animal Sciences, 6, 195-201. https://doi.org/10.4236/ojas.2016.63025

[6] McKinnon, J. and Liley, N. (1986) Asymmetric Species in Response to Female Sexual Pheromones by Males of Two One Male and One Female (Control) One Male and Three Females Species of Trichogaster (Pisces: Belontidae). Canadian Journal of Zoology, 65, 1129-1134. https://doi.org/10.1139/z87-176

[7] Miller, J.R. (1964) Studies on the Social Behavior of the Blue Gourami, Trichogaster trichopterus (Pisces, Belontiidae). Copeia, 3, 469-496.

https://doi.org/10.2307/1441512

[8] Degani, G. (2001) The Effect of Temperature, Light, Fish Size snd Container Size on Breeding of Trichogaster trichopterus. Israel Journal of Aquaculture, 41, 67-73.

[9] Degani, G. (2020) Brain Control Reproduction by the Endocrine System of Female 
Blue Gourami (Trichogaster trichopterus). Biology, 9, 109. https://doi.org/10.3390/biology9050109

[10] Degani, G. (1993) The Effect of Sexual Behavior on Oocyte Development and Steroid Changes in Trichogaster trichopterus. Copeia, 4, 1091-1096. https://doi.org/10.2307/1447089

[11] Becker, D., Galili, N. and Degani, G. (1992) GCNS-Identified Steroids and steroids goucoronides in Gonads and Holding Water in Gonads and Holding Water of Trichogaster tricopterus (Anabantidea, Pallas 1770). Comparative Biochemistry and Physiology Part B: Comparative Biochemistry, 103, 15-19. https://doi.org/10.1016/0305-0491(92)90406-H

[12] Degani, G.; Schreibman, M.P. (1993) Pheronome of Male Blue Gourami and Its Effect on Vitellogenesis, Steroidogenesis and Cells in Pituitary of Female. The Journal of Fish Biology, 43, 475-485.

[13] Yaron, Z. and Levavi-Sivan, B. (2011) Endocrine Regulation of Fish Reproduction. In: Farrell, A.P., Ed., Encyclopedia of Fish Physiology: From Genome to Environment, Academic Press, Cambridge, 1500-1508. https://doi.org/10.1016/B978-0-12-374553-8.00058-7

[14] Degani, G. (2016) Oogenesis Control in Multi-Spawning Blue Gourami (Trichogaster trichopterus) as a Model for the Anabantidae Family. Internal Journal of Scientific Research, 5, 179-184.

[15] Degani, G., Alon, A., Stoler, A. and Bercocvich, D. (2017) Evidence of a Reproduction-Related Function for Brine Kisspeptin 2 and Its Receptors in Anabantidae Fish (Trichogaster trichopterus). International Journal of Zoological Investigations, 2, 106-122.

[16] Levy, G. and Degani, G. (2012 Involvement of GnRH, PACAP and PRP in the Reproduction of Blue Gourami Females (Trichogaster trichopterus). Journal of Molecular Neuroscience, 48, 9730-9738. https://doi.org/10.1007/s12031-012-9730-8

[17] Levy, G. and Degani, G. (2013) The Role of Brain Peptides in the Reproduction of Blue Gourami Males (Trichogaster trichopterus). Journal of Experimental Zoology Part A: Ecological Genetics and Physiology, 319, 461-470.

https://doi.org/10.1002/jez.1809

[18] Levy, G., Goldberg, D., Jackson, K. and Degani, G. (2010) Association between Pituitary Adenylatecyclase Activating Polypeptide and Reproduction in the Blue Gourami. General and Comparative Endocrinology, 166, 83-93.

https://doi.org/10.1016/j.ygcen.2009.09.015

[19] Degani, G., Jackson, K., Goldberg, D., Sarfati, R. and Avtalion, R. (2003) FSH, LH and Growth Hormone Gene Expiration in Blue Gourami (Trichogaster trichopterus, Pallas, 1770) during Spermatogenesis and Male Sexual Behavior. Zoological Science, 20, 737-743. https://doi.org/10.2108/zsj.20.737

[20] Degani, G. and Yom Din, S. (2011) Hormones Transcription in the Testis of Blue Gourami (Trichogaster trichopterus, Pallas 1770) during Sexual Behavior. Bulletin UASVM Animal Science and Biotechnologies, 68, 43-50.

[21] Mananos, E., Zohar, Y. and Degani, G. (1997) The Relationship between Gonadotropin and Sexual Behavior of Male Trichogaster trichopterus (Pallas). Indian Journal of Fisheries, 44, 239-246.

[22] Degani, G. (2014) Expression of the Growth Hormone and Insulin-Like Growth Factor 1 Genes in the Male and Female Blue Gourami (Trichogaster trichopterus) at Different Temperatures. Journal of Asian Scientific Research, 4, 413-427.

[23] Degani, G., Yom-Din, S., Goldberg, D. and Jackson, K. (2010) cDNA Cloning of 
Blue Gourami (Trichogaster trichopterus) Prolactin and Its Expression during the Gonadal Cycles of Males and Females. Journal of Endocrinological Investigation, 33, 7-12. https://doi.org/10.1007/BF03346543

[24] Degani, G. (2017) Steroids Controlled by Various Hormones Influence Oogenesis and Spermatogenesis of the Model Fish, Trichogaster trichopterus (Anabantidae, Pallas). Avid Science Publication, 1-31.

[25] Degani, G. and Boker, R. (1992) Vitellogenesis Level and the Induction of Maturation in the Ovary of the Blue Gourami Trichogaster trichopterus (Anabantidae, Pallas 1770). Journal of Experimental Zoology, 263, 330-337. https://doi.org/10.1002/jez.1402630313

[26] Degani, G.; Boker, R. (1992) Sensitivity to Maturation Inducing Steroids and Gonadotropin in the Oocytes of Blue Gourami Trichogaster trichopterus, (Anabantidae, Pallas, 1770). General and Comparative Endocrinology, 85, 430-439. https://doi.org/10.1016/0016-6480(92)90088-2

[27] Cheal, M. and Davis, R.E. (1974) Sexual Behavior: Social and Ecological Influences in the Anabantoid Fish, Trichogaster trichopterus. Behavioral Biology, 10, 435-445. https://doi.org/10.1016/S0091-6773(74)92009-4

[28] Degani, G. (2015) 11-Ketotesterone (KT-11), Estradiol Estradiol (E2) Level and Cytochrome P450 (bgCYP19a) Ttranscription of in the Testis of Male Blue Gourami (Trichogaster trichopterus). International Journal of Science and Research, 4, 641-643.

[29] David, D. and Degani, G. (2011) Effect of Temperature on Gene Expression of Hormones that Control Growth and Reproduction in the Male Blue Gourami (Trichogaster trichopterus). Journal of Experimental Zoology, 313A, 1-11.

[30] Levy, G. and Degani, G. (2011) Evidence for a Reproduction-Related Function of Pituitary Adenylatecyclase-Activating Polypeptide-Related Peptide (PRP) in an Anabantidae Fish. Journal of Molecular Endocrinology, 46, 101-110. https://doi.org/10.1530/JME-10-0065

[31] Degani, G., Jackson, K., Yom-Din, S. and Goldberg, D. (2006) cDNA Cloning and mRNA Expression of Growth Hormone in Belontiidae (Anabantoidei suborder) Fish. Israel Journal of Aquaculture, 58, 124-136.

[32] Hull, K.L. and Harvey, S. (2014) Growth Hormone and Reproduction: A Review of Endocrine and Autocrine/Paracrine Interactions. International Journal of Endocrinology, 2014, Article ID: 234014. https://doi.org/10.1155/2014/234014 